\title{
Parameters for Mining of Gold Monitoring System using Zigbee Standard
}

\author{
Mohanraj, Balaji.S, John Paul Praveen.A
}

\begin{abstract}
The proposed work is to monitor the underground Gold mining gas leakage system using zigbee module. In the existing system, whenever the parameter values increases above the threshold value, then a message will be sent. In this current system the information send from the main server to all workers, if the conditions become unfavourable in the working place, mine workers will be alerted to leave the place, through which the Gold mine accidents can be avoided. So the productivity can be increased and safety to the Gold mining process.

Keywords : PIC16F877, Mine Safety, ZigBee, LCD, RFID,
\end{abstract} Temperature Sensor, Humidity, Threshold value.

\section{INTRODUCTION}

Safety is the most vibrant component of any kind of industry. Safety and welfare in the mining industry is a key characteristic of all. In order to prevent any kind of unwanted event, all mining companies have some fundamental safeguards in place. Interaction is the most potent impact today, it is to measure distinct variables such as heat, growing moisture, and carbon monoxide, methane, etc., The communication network must not be sporadic at any moment and at any condition. In the Inside underground mines, the wired communication network system is not so active. For the successful Mobile broadband transfer, the zig-bee scheme of the mine is used in modems. [1-8]

\section{II.OBJECTIVE}

1) Monitoring: To monitor the parameters like carbon monoxide(co), temperature and humidity level detection.

2) Communication:

3) Rescue method: Whenever the information or data from the sensor exceeds the specified threshold, the zigbee module at remote monitoring and temperature, gas, humidity and number of persons Depending on the evolving scenario, it will be presented on the LED section. 4) Privacy: by means of a zig-bee data transmission scheme, staff who are working in the Gold mine environment will be alert earlier. So rapid action will be taken and Depending on the evolving scenario,

Revised Manuscript Received on August 22, 2019.

Mohanraj Assistant Professor, Department of Electronics And Communication Engineering,, Bharath Institute of Higher Education and Research, Chennai, Indiadspmohanraj@gmail.com

Balaji.S, Assistant Professor, Department of Electronics And Communication Engineering,, Bharath Institute of Higher Education and Research, Chennai, India bala.sripathy@gmail.com

John Paul Praveen. Assistant Professor, Department of Electronics And Research, Chennai, India . johnpaul.embedded@gmail.com Communication Engineering, Bharath Institute of Higher Education and

it will be presented on the LED section. 4) Privacy: by means of a zig-bee data transmission scheme, staff[9-13]

\section{III.EXISTING SYSTEM}

Due to homogeneity, some nodes are getting over burdened.The information will be send only to the authorized user through modem. Highly efficient nodes are wasted in low level applications. In the existing system, continuous data collection from the fixed node to sink node, this will result in energy wastage as well as false detection[14-16]

\section{IV.PROPOSED SYSTEM}

It provides a higher ability to recover from errors. The networks are highly efficient, with highest QoS(Quality of Service). The event detection is the major application over existing system, this will cause energy consumption. While using continuous data collection it will result in data congestion, data losses. It will be reduced in proposed system. The information will be send to all workers about the environmental factors, which may help the workers to avoid the accidents.

\section{V.DESCRIPTION}

Three parts available in this system. Those are monitoring unit, sensing unit and person availability checking unit. The block diagrams of each unit are as shown in the following figure. Each unit has one microcontroller. Monitoring unit will receive a data from the sensing unit whereas sensing unit is continuously monitoring the above mentioned data's.

The methane concentration, temperature level and the moisture level has been sensed and send to the monitoring unit simultaneously. Another unit is a person availability checking unit. Every employee has this unit to check their presence. It is also will send to the monitoring unit. So the monitoring unit will monitor the sensing data as well as the availability of the employees. [17-19]

- Mobile Nodes-transmits the unique employee id and also receives warning messages from fixed nodes. They are carried by the mine workers.

- The nodes are communicating with each other and forms a wireless network.[20]

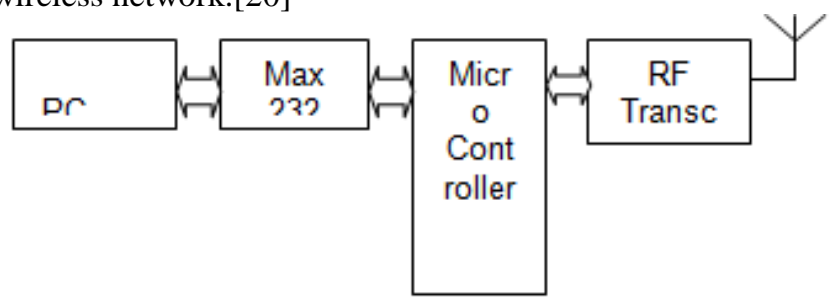

Fig:1 sink node 


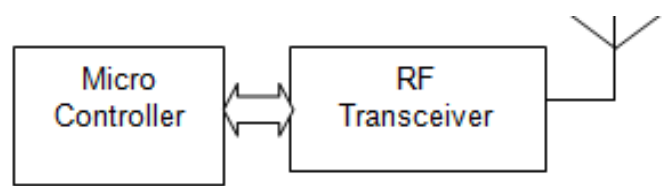

Fig:2 mobile node

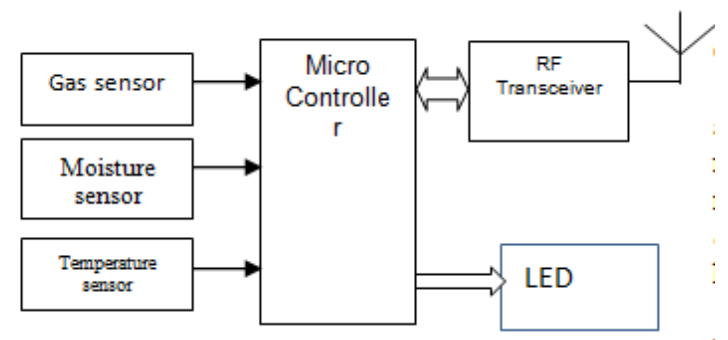

\section{Fig:3 fixed node VI.HARDWARE DESIGN}

\section{A. Microcontroller}

It includes EEPROM, timer, analog comparator, UART. It is an 8-bit architecture and it is said to be RISC processor. It can support I2C, SPI protocols. It is a 40 pin package. External crystal can go up to $20 \mathrm{MHz}$.

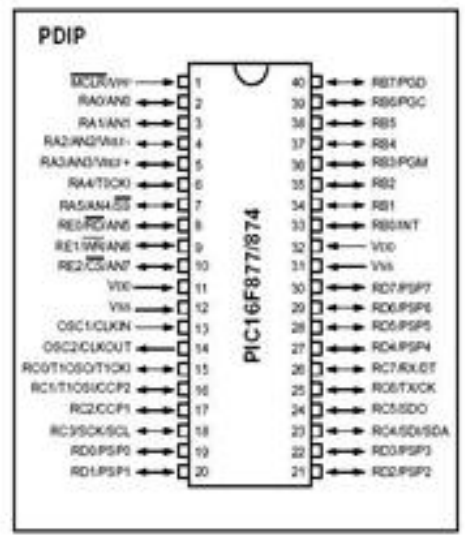

\section{B. Gas Sensor}

This sensor is used to sense the leakage of this stated gas. It goes 'high', when the specified gas sensed. The output of the sensor goes LOW as hurriedly as the gas sensor senses any gas leakage from that storage. This is detected by the microcontroller and the buzzer is turned ON. The output of sensor is connected to the PIC microcontroller (port A or E).

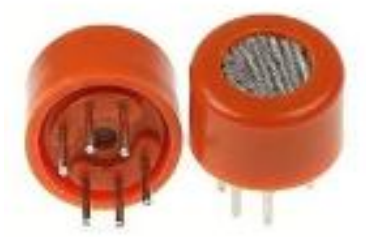

C. Display Unit

It is said to be liquid crystal display and is used to display the content from the microcontroller. Here we use $2 \times 16$ alpha-numeric LCD. It has two line and we can display maximum of 16 characters on each line.

\section{Power supply unit:}

The power supply unit consists with four units. To convert the AC to DC the output is fed into the bridge rectifier. To remove the harmonics we used capacitor and finally the output is fed into the voltage regulator. It will produce the constant DC voltage depends on the voltage regulator IC's.

\section{E. Rf encoder:}

RF Encoder (HT12E) is used to transmit digital data, it operates in Radio Frequency. Data to be transmitted are encoded with 8-bit or 4-bit data and it is sent to the RF transmitter.

\section{F. Decoder:}

RF Decoder (HT12D) is used to decode the data transmitted by the transmitter.

\section{VII.SOFTWARE DESIGN OUTPUT}

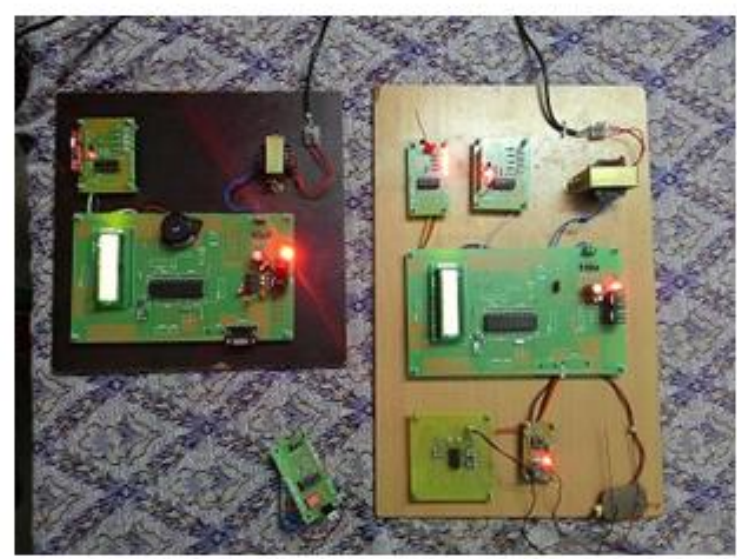

\section{VIII.CONCLUSION}

The earlier gold coalfield safety scheme can be perfectly swapped by finding the number of persons as well as Gold mine parameters (temperature, gas, humidity) values and alerting them is proposed in the paper.

\section{REFERENCES}

1. Kongkham, D. \& Sundararajan, M. 2019, "Distributed wideband sensing method for faded dynamic spectrum access", International Journal of Innovative Technology and Exploring Engineering, vol. 8, no. 10, pp. 4309-4312.

2. Balaji, S., John Paul Praveen, A. \& Mohanraj, R. 2019, "Recognizable proof and analysis of palm print in biometric authentication system using bayes techniques", International Journal of Innovative Technology and Exploring Engineering, vol. 8, no. 9 Special Issue 3, pp. 1126-1129.

3. Kavitha, G., Priya, N., Velvizhi, R. \& Allin Geo, A.V. 2019, "Parallel computation in correspondence and signal processing", International Journal of Innovative Technology and Exploring Engineering, vol. 8, no. 9 Special Issue 3, pp. 1136-1139.

4. Hema, R., Sundararajan, M. \& Balaji, S. 2019, "Smartphone control robot with automatic firing gun", International Journal of Innovative Technology and Exploring Engineering, vol. 8, no. 9 Special Issue 3, pp. 625-627.

5. Kaliyamurthie, K.P., Sundar Raj, B., Velvizhi, R. \& Shanmugapriya, K 2019, "Dual band paper substrate CPW antenna for wireless applications", International Journal of Innovative Technology and Exploring Engineering, vol. 8, no. 9 Special Issue 3, pp. 605-608.

6. Geo, A.V.A., Arunachalam, A.R., Michael, G. \& Elankavi, R. 2019, "Evaluating architecture using compact modalities", International Journal of Innovative Technology and Exploring Engineering, vol. 8, no. 9 Special Issue 3, pp. 836-838.

7. Theivasigamani, S., Jeyapriya, D. \& Anita Davamani, K. 2019 , "Anamoly analyzing and exploring for wireless sensor networks", International Journal of Innovative Technology and Exploring Engineering, vol. 8, no. 9 Special Issue 3, pp. 1116-1118.

8. Jeyapriya, D., Theivasigamani, S., Velvizhi, R. \& Nandhini, P. 2019, "Program detection in wireless feeler networks", International Journal of Innovative Technology and Exploring Engineering, vol. 8, no. 9 Special Issue 3, pp. 1194-1195.

9. Gowri Sankaran, B., Karthik, B. \& Vijayaragavan, S.P. 2019, "Image compression utilizing wavelet transform", International Journal of Innovative

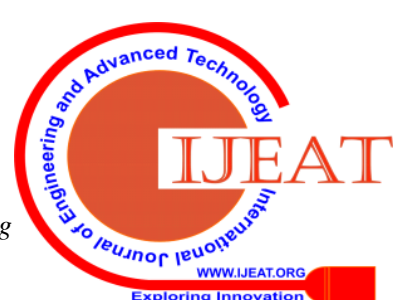


Technology and Exploring Engineering, vol. 8, no. 10, pp. 4305-4308.

10. Gowri Sankaran, B., Karthik, B. \& Vijayaragavan, S.P. 2019, "Weight ward change region plummeting change for square based image huffman coding", International Journal of Innovative Technology and Exploring Engineering, vol. 8, no. 10, pp. 4313-4316.

11. Hema, R., Sundararajan, M. \& Balaji, S. 2019, "Smartphone control robot with automatic firing gun", International Journal of Innovative Technology and Exploring Engineering, vol. 8, no. 9 Special Issue 3, pp. 625-627.

12. Rangaswamy, K. \& Rajabhushanam, C. 2019, "Congestion control in wireless network using TCP friendly rate control (TFRC)", International Journal of Recent Technology and Engineering, vol. 8, no. 2 Special issue 3, pp. 1598-1602.

13. Tamil Selvan, S. \& Sundararajan, M. 2019, "Performance Parameters of 3 Value $8 \mathrm{t}$ Cntfet Based Sram Cell Design Using H-Spice", International Journal of Recent Technology and Engineering, vol. 8, no. 2 Special issue 5, pp. 22-27.

14. Vinoth, V.V. \& Kanniga, E. 2019, "Steganographical techniques in hiding text images - system", International Journal of Recent Technology and Engineering, vol. 8, no. 2, pp. 6535-6537.

15. Saravana, S., Balaji, S., Arulselvi, S. \& John Paul Praveen, A. 2019 "Reliable power quality monitoring and protection system", International Journal of Innovative Technology and Exploring Engineering, vol. 8, no. 9 Special Issue 3, pp. 644-645.

16. Sundaramoorthy, A. \& John Wiselin, M.C. 2019, "Single patch antenna with multiple feed", International Journal of Innovative Technology and Exploring Engineering, vol. 8, no. 9, pp. 1743-1747.

17. Velavan, R., Bharanidharan, S. \& Sheeba, B. 2019, "EMF pollution Causes, effects and protection", International Journal of Innovative Technology and Exploring Engineering, vol. 8, no. 9 Special Issue 3, pp. 1166-1168.

18. Veer, R.A., Arulselvi, S. \& Karthik, B. 2019, "Construction of ensemble square classification approaches in MIMO OFDM", International Journal of Engineering and Advanced Technology, vol. 8, no. 5, pp. 2039-2041.

19. Agitha, W. \& Kaliyamurthie, K.P. 2019, "Improved energy efficient in WBAN using MAC with cloud computing", International Journal of Innovative Technology and Exploring Engineering, vol. 8, no. 8, pp. 2405-2408.

20. Kastro, G.G. \& Wiselin, M.C.J. 2019, "Design and analysis of stub loaded resonator", International Journal of Recent Technology and Engineering, vol. 8, no. 1 Special Issue4, pp. 272-283.

\section{AUTHORS PROFILE}

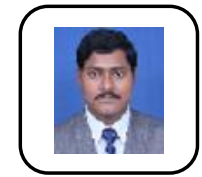

Mohanraj Assistant Professor, Department of Electronics And Communication Engineering,, Bharath Institute of Higher Education and Research, Chennai, India.



Balaji.S,, Assistant Professor, Department of Electronics And Communication Engineering,, Bharath Institute of Higher Education and Research, Chennai, India.

John Paul Praveen. Assistant Professor, Department of Electronics And Communication Engineering,, Bharath Institute of Higher Education and Research, Chennai, India. 